\title{
УДК 656.135
}

\section{І. Я. СКОВРОН ${ }^{*}$, А. С. ДОРОШ ${ }^{2 *}$, Є. Б. ДЕМЧЕНКО ${ }^{3 *}$, Т. В. БОЛВАНОВСЬКА ${ }^{4 *}$, В. В. МАЛАШКІН ${ }^{5 *}$}

\author{
1* Каф. «Транспортні вузли», Дніпровський національний університет залізничного транспорту імені академіка В. Лаза- \\ ряна, вул. Лазаряна, 2, м. Дніпро, Україна, 49010, тел. +38 (095) 23050 34, ел. пошта: norvoks@ gmail.com, \\ ORCID 0000-0003-0697-2698 \\ ${ }^{2 *}$ Каф. «Транспортні вузли», Дніпровський національний університет залізничного транспорту імені академіка В. Лаза- \\ ряна, вул. Лазаряна, 2, м. Дніпро, Україна, 49010, тел. +38 (066) 92784 62, ел. пошта: dorosh.andrii@ gmail.com, \\ ORCID 0000-0002-5393-0004 \\ $3^{*}$ Каф. «Транспортні вузли», Дніпровський національний університет залізничного транспорту імені академіка В. Лаза- \\ ряна, вул. Лазаряна, 2, м. Дніпро, Україна, 49010, тел. +38 (097) 79916 75, ел. пошта: e.b.dmch@ gmail.com, \\ ORCID 0000-0003-1411-6744 \\ $4^{*}$ Каф. «Транспортні вузли», Дніпровський національний університет залізничного транспорту імені академіка В. Лаза- \\ ряна, вул. Лазаряна, 2, м. Дніпро, Україна, 49010, тел. +38 (056) 373-15-12, ел. пошта: valentinovna.upp@ gmail.com, \\ ORCID 0000-0001-6462-8524 \\ $5^{*}$ Каф. «Транспортні вузли», Дніпровський національний університет залізничного транспорту імені академіка В. Лаза- \\ ряна, вул. Лазаряна, 2, м. Дніпро, Україна, 49010, тел. +38 (056) 373-15-12, ел. пошта: viacheslav.malashkin@ gmail.com, \\ ORCID 0000-0002-5650-1571
}

\section{ПІДВИЩЕННЯ ЕФЕКТИВНОСТІ ДОСТАВКИ ЗБІРНИХ ВАНТАЖІВ АВТОМОБІЛЬНИМ ТРАНСПОРТОМ}

Мета. Дослідження загальноприйнятої системи організації транспортного обслуговування автотранспортним підприємством, удосконалення технології планування перевезень та оптимізація процесу доставки збірних вантажів від місць їх консолідації до кінцевих споживачів (підприємств, складів, торгових точок, пошти та ін.). Методика. При формулюванні задачі дослідження важливим $є$ врахування максимальної кількості найбільш впливових факторів: обсяги перевезених партій вантажів; географічне розташування місць консолідації та завантаження вантажів, а також кінцевих споживачів; тип і вантажопідйомність рухомого складу; терміни доставки вантажів; особливі умови виконання вантажно-розвантажувальних робіт тощо. Задача визначення оптимального маршруту вирішувалась як задача комівояжера з використанням методів комбінаторної оптимізації, логістики та одного із евристичних методів. Результати. У даній статті були виконані дослідження різних методів планування маршруту руху автомобіля при доставці збірних вантажів до кінцевих споживачів. В результаті були отримані рекомендації щодо вибору методу планування маршрутів доставки вказаних вантажів у тій чи іншій ситуації. Практична значимість. Незважаючи на те, що дрібнопартійні перевезення становлять незначну частку від загальної транспортної роботи, однак транспортні витрати на них сягають третини всіх витрат. У зв'язку з цим, раціональне вирішення питання маршрутизації $\epsilon$ необхідним для ефективного управління перевізним процесом та скорочення витрат енергетичних ресурсів при виконанні транспортної роботи з обслуговування кінцевих споживачів. Це дозволить знизити собівартість перевезення вантажу та покращити економічні показники роботи автотранспортного підприємства в цілому.

Ключові слова: автомобільний транспорт; дрібнопартійні вантажі; підвищення ефективності доставки; задача комівояжера; обслуговування кінцевих споживачів

\section{Вступ}

Транспортна система будь-якої розвинутої країни $є$ вагомою умовою для їі цілісності та незалежності за рахунок забезпечення національної безпеки, обороноздатності, розвитку зовнішньоекономічних зв'язків та безупинне функціонування різних галузей економіки країни. Крім того, розвинута транспортна інфраструктура забезпечує швидкий та комфортний взаємозв'язок між людьми, регіонами, містами, країнами та континентами, що сприяє культурному та духовному обміну, задоволенню естетичних потреб населення, що в підсумку призводить до покращення умов його життя.

Враховуючи вигідне географічне розташування України, чітка взаємодія елементів транспортної системи та їх розвиток створюють передумови для економічного росту та сприяють зміцненню взаємовідносин з іншими державами.

Крім виконання макроекономічних функцій транспорт також $є$ невід'ємною частиною будьякого виробництва, оскільки виконує регулярну доставку сировини, палива та готової продукції 3 пунктів їх виробництва або консолідації до пунктів споживання.

Таким чином, можна стверджувати, що забезпечення чіткої та злагодженої роботи всіх 
елементів транспортної системи повинно бути прерогативою у стратегії розвитку нашої країни.

\section{Аналіз літературних джерел}

Національну транспортну систему України в основному формують залізничний, автомобільний, річний, морський, повітряний та трубопровідний види транспорту, однак роль, яку вони відіграють, суттєво відрізняється. Використовуючи дані Державної служби статистики України [1], проаналізуємо обсяги перевезених вантажів різними видами транспорту за останні 10 років.

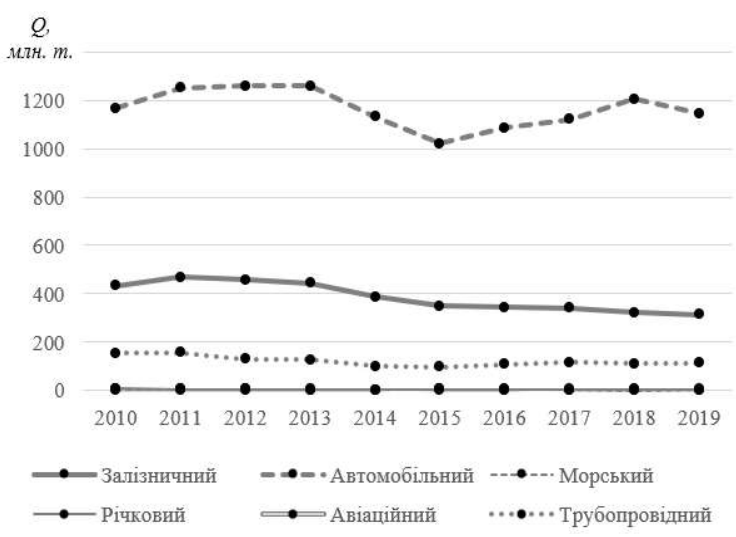

Рис. 1. Аналіз обсягів перевезення вантажів по Україні різними видами транспорту

Як видно з рис. 1, обсяги перевезення вантажів залізничним транспортом за останні 10 років упевнено знижуються, у той час як у автомобільного транспорту як правило спостерігається суттєве зростання. Вказані дані можна пояснити основними перевагами автомобільного транспорту по відношенню до інших видів транспорту, серед яких можна відзначити високу маневреність, можливість доставки вантажів «від дверей до дверей», забезпечення регулярності поставок вантажів, а також постачання вантажів як крупними так і дрібними партіями.

На рис. 2 за даними [1] наведено середні відстані перевезення 1 тони вантажу різними видами транспорту у 2018 році.

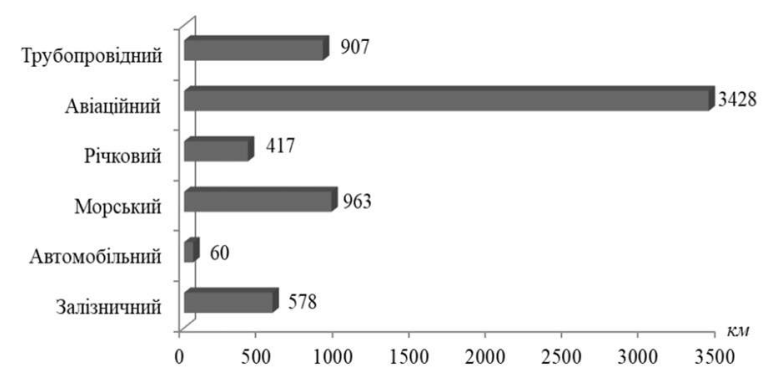

Рис. 2. Середня відстань перевезення 1 т вантажу різними видами транспорту у 2018 році
Як видно 3 рис. 2, середня відстань переміщення 1 тони вантажу автотранспортом значно менше ніж для інших видів транспорту, що вказує на специфіку його роботи. Так, автомобільний транспорт в основному застосовується для перевезення товарів від станцій залізниць, морських та річкових портів, зі складів виробничих і сільськогосподарських підприємств на склади оптових підприємств, а потім і з цих складів до об'єктів торгівельних мереж, для переміщення товарів між магазинами і для виїзної торгівлі.

Середньодобовий обсяг перевезення вантажів за видами транспорту в 2018 році показано на рис. 3 .

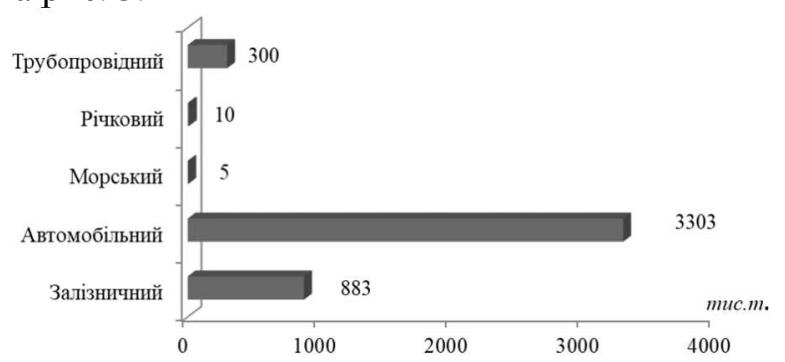

Рис. 3. Середньодобовий обсяг перевезення вантажів за видами транспорту в 2018 році

Згідно 3 рис. 3 , в середньому за добу автомобільним транспортом виконується перевезення близько 3303 тис. т. вантажів, що є найбільшим показником за видами транспорту.

Основною продукцією вантажних автомобільних перевезень $\epsilon$ [1]: продукція добувної промисловості (32,7 млн. т); харчові продукти (10,9 млн. т); продукція сільського та лісового господарств, мисливства (9,3 млн. т); неметалева мінеральна продукція (7,7 млн. т); деревина та вироби з дерева (3,14 млн. т), а також кокс 3 вугіллям (3,0 млн тис. т) [1].

В публікації [2] автори констатують зростання обсягів перевезень автотранспортом, однак відмічають, що такий тренд вимагає посилення контролю $з$ метою функціонування автотранспортних підприємств виключно у правовому полі. Це дозволить захистити інтереси споживачів автотранспортних послуг і забезпечити його ефективне регулювання державою. Так, на даний момент склалася ситуація, за якої ліцензія потрібна лише для автопідприємств, які здійснюють перевезення небезпечних вантажів у внутрішньому та міжнародному сполученнях, а також для міжнародних перевезень вантажів, у той час як для інших видів перевезень ліцензія не потрібна. Це, на думку авторів, може негативно впливати на якість надання транспортних послуг, оскільки перевірка стану автотранспортних засобів та професійних компетенцій водіїв 
покладена на керівництво автопідприємств (без регулярного зовнішнього контролю), що може викликати недобросовісне виконання існуючих вимог законодавства та, в окремих випадках, не виключає виникнення проблемних ситуацій при наданні транспортних послуг.

Проблема вибору способу транспортного забезпечення вирішується на основі критеріїв, які $\epsilon$ пріоритетними для власника вантажу. Найбільш часто їх оцінюють за такими критеріями [3]:

- мінімум витрат на перевезення;

- мінімум часу доставки товару;

- мінімум ризику несвоєчасної доставки;

- максимум провізної здатності транспорту;

- готовність до перевезення в різних умовах;

- мінімум втрат вантажу при перевезенні.

Крім того, можуть враховуватись також фінансовий стан перевізника, наявність додаткових послуг 3 експедиційного обслуговування, комплектації і доставки вантажу, гнучкість маршруту транспортних засобів, можливість переадресації вантажу в дорозі, регулярність роботи транспорту, компетентність персоналу та якість транспортних послуг, можливість контролю руху товару в дорозі за допомогою засобів геолокації, відсутність негативного впливу на навколишнє середовище тощо. Перелік факторів, які можуть враховуватись тим чи іншим споживачем транспортних послуг при виборі автоперевізника, може суттєво відрізнятись.

Перевезення вантажу багато в чому визначається експлуатаційними якостями рухомого складу, серед яких важливими є пристосованість до вантажно-розвантажувальних робіт, плавність ходу, маневреність, готовність до руху, запас ходу, компактність, прохідність та вантажомісткість.

В сучасних умовах автомобільним транспортом здійснюється обслуговування як ряду промислових підприємств, так і торгових точок міста. 3 розвитком різноманітних галузей бізнесу у значної кількості споживачів зростає потреба в дрібнопартійних перевезеннях (як правило, від 10 кг до 2000 кг) вантажів широкої номенклатури [4]. Потенційними споживачами послуг доставки невеликих партій продукції є підприємства і організації різних форм власності, а також індивідуальні підприємці. Велику частину клієнтів складають постійні споживачі: на їх частку припадає переважна частина перевезених обсягів дрібнопартійних вантажів [5].

Відносно недавно основною метою діяльності автопідприємства 3 доставки вантажів було лише виконання ним плану перевезення. Однак у сучасних умовах акценти значно змінились i з'явилось розуміння, що головною метою для такого підприємства повинна бути доставка потрібної кількості та якості вантажу у вказані місце й час 3 мінімальними витратами. Традиційні технології транспортного обслуговування не можуть забезпечити потрібних результатів, тому 3 цією метою доцільно використовувати комплексний логістичний підхід до організації перевізного процесу, адже в умовах жорсткої конкуренції будь-яке автотранспортне підприємство повинно чітко реагувати на зміни ринку транспортних послуг та бути зацікавленим не лише в отриманні прибутку, а й у повному задоволенні потреб кінцевого споживача.

Останнім часом паралельно 3 розбудовою міст відбувається збільшення кількості торгових точок, що викликає зростання обсягів перевезень вантажів. Таким чином, попит на транспортне обслуговування підприємств шляхом доставки товарів дрібними партіями зростає. Даний вид доставки найбільш характерний для торгівлі та транспортування соціально важливих вантажів, продовольчих товарів, вантажів сфери побутового обслуговування, пошти і т. д. [5].

Для досягнення оптимального варіанту функціонування усіх складових транспортної системи (виробництво, зберігання, доставка, реалізація) необхідно використовувати сучасні логістичні принципи та методики [6]. Одним 3 логістичних способів зниження витрат $є$ оптимізації розміру партії вантажу при організації постачання вантажів на розподільчі склади або безпосередньо вантажоодержувачу, адже зі збільшенням партії одноразової доставки зростають запаси продукції на складах, що призводить до збільшення поточних витрат на іiі зберігання, однак скорочуються питомі витрати на навантаження, транспортування вантажів. Як вказують автори публікації, оптимальний обсяг партії може бути знайдений виходячи 3 методики управління запасами.

Можна відмітити, що даний підхід може бути ефективним для підприємства-постачальника, 3 високим темпом виробництва продукції, проте не завжди реалізується для обслуговування, наприклад, роздрібних торгових точок.

Крім того, слід відмітити, що перевезення дрібних партій вантажу є дорогим процесом. У роботах $[5,7]$ автори з'ясували, що при перевезенні масових вантажів транспортні витрати значно нижче, ніж при доставці дрібних партій вантажів. Їх дослідження показали, що хоч дрібнопартійні перевезення і становлять близько $3 \%$ від загальної транспортної роботи, проте 
транспортні витрати на ці перевезення можуть складати 25-35\% від усіх витрат (нераціональний вибір маршрутів руху призводить до перевищення пробігу автомобілів).

\section{Постановка задачі дослідження}

Таким чином, підвищення ефективності доставки збірних вантажів автомобільним транспортом до кінцевих споживачів є важливою та актуальною науково-практичною проблемою, вирішенням якої уже тривалий час займається численна когорта світових науковців.

Далі у статті виконано дослідження вказаної проблеми як задачі комівояжера.

\section{Методика вирішення}

Вказана проблема є одним з найбільш поширених різновидів задач маршрутизації.

Організацію транспортного обслуговування необхідно здійснювати за умови мінімізації нераціональних пробігів, які безпосередньо впливають на величину загального пробігу автомобіля. Одним із методів підвищення ефективності технології розвізних маршрутів може бути доставка попутних партій вантажу від декількох виробників, тобто спільне розвезення сумісних вантажів (як безпосередньо зі складів цих виробників, так і з центру їх консолідації). Це дозволить знизити величину холостих пробігів, а також підвищити продуктивність транспортної роботи.

Удосконалення організації транспортного обслуговування кінцевих споживачів міста шляхом дрібнопартійних перевезень передбачає рішення оптимізаційних задач. Задачі маршрутизації передбачають [8]: відомі місцезнаходження вантажовідправників і вантажоодержувачів; обсяги вивезення і завезення вантажів; рухомий склад; транспортна мережа, а також умови руху. Необхідно знайти такі впорядковані множини пунктів, пов'язаних між собою, які формують маршрути, а доставка вантажів ними приводить до досягнення оптимального значення заданої цільової функції.

Згідно [9] у загальному вигляді задачі маршрутизації транспорту при перевезенні вантажів можна записати наступним чином.

Задана матриця ваги транспортного графу

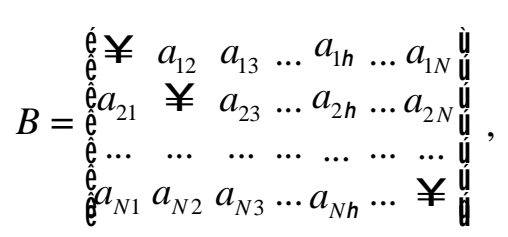

де $a_{N \mathrm{~h}}$ - вага дуги (відстань, час, витрати, робота) між пунктами транспортної мережі.

Потрібно мінімізувати цільову функцію

$$
f(B)=\hat{\mathrm{A}} a_{N \mathrm{~h}} \text { Æ } \min ,
$$

Обмеження при цьому будуть наступними

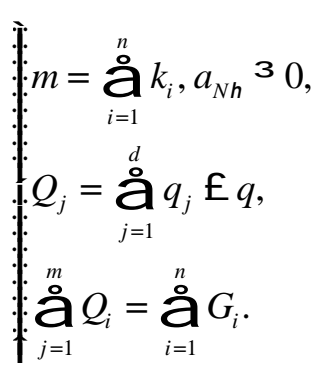

де $q_{j}$ - кількість вантажу в $j$-му пункті;

$q$ - вантажопідйомність автомобіля;

$G_{i}$ - кількість вантажу на $n$-й базі.

При $a_{i j} \pi a_{j i}$ матриця (1) буде несиметричною.

Задача маршрутизації є складною математичною проблемою, яку можна вирішувати за допомогою методів математичного моделювання. Для цього необхідно визначити набір пунктів, які входять в цикл перевезень, а також знайти послідовність їх об'їзду. Вказана проблема може бути вирішена за допомогою задачі комівояжера.

Задача комівояжера - одна 3 найвідоміших задач комбінаторної оптимізації. Проблема вирішення цієї задачі вперше офіційно з'явилася в наукових колах в 1832 році, проте оптимальні методи іï вирішення почали з'являтися тільки в середині минулого століття, коли вона була представлена в якості задачі дискретної оптимізації. В умовах задачі вказуються критерій оптимальності маршруту (найкоротший чи найдешевший) і відповідні матриці відстаней або вартості. Задача вирішується на основі циклу Гамільтона, тобто такого замкнутого шляху, який проходить через кожну вершину графа рівно по одному разу [10].

Задача комівояжера полягає в тому, що аналізує $n$ пунктів, з одного із яких виїжджає комівояжер і об'їжджає всі пункти за умови, що він відвідає кожен пункт лише один раз. Відстань між ними не однакова, тому кожна послідовність пунктів дає різну сумарну відстань пробігу. Потрібно знайти такий порядок відвідування пунктів, щоб сумарна пройдена відстань була мінімальною, і комівояжер повернувся в той пункт, 3 якого почав свій маршрут. Іншими словами, в підвішеному повному графі потрібно 
знайти цикл Гамільтона мінімальної ваги $[10,11]$. Маршрут буде оптимальним, якщо на ньому досягається критичне значення цільової функції. Так, наприклад, цільова функція (2) описує зміни основного критерію оптимізації (пробігу автомобіля, часу руху, транспортної роботи, транспортних витрат); також для неї наведений ряд обмежень (3).

Задача комівояжера відноситься до числа трансобчислювальних, оскільки кількість можливих маршрутів факторіально залежить від кількості точок (існує $(n-1)$ ! маршрутів для асиметричної задачі та $(n-1) ! / 2$ для симетричної задачі комівояжера). Вже при не дуже значній кількості пунктів вона може не бути вирішена методом повного перебору варіантів за прийнятний час навіть на дуже продуктивних ЕОМ. У таблиці 1 наведені дані про кількість маршрутів для деякої мережі $3 n$ пунктів та прогнозований час пошуку оптимального маршруту для неї на деякій ЕОМ, що може обробляти умовно $10^{6}$ варіантів за секунду.

Таблиця 1

Параметри пошуку оптимального маршруту обходу всіх точок мережі повним перебором

\begin{tabular}{c|c|c|c|c|c}
\hline $\begin{array}{c}\text { Кількість } \\
\text { точок } n\end{array}$ & 10 & 15 & 20 & 30 & 100 \\
\hline $\begin{array}{c}\text { Маршру- } \\
\text { тів }\end{array}$ & $1,8 \cdot 10^{5}$ & $4,4 \cdot 10^{10}$ & $6,1 \cdot 10^{16}$ & $4,1 \cdot 10^{33}$ & $4,7 \cdot 10^{155}$ \\
\hline $\begin{array}{c}\text { Час по- } \\
\text { шуку }\end{array}$ & $0,2 \mathrm{c}$ & 12 год & $1928 \mathrm{p}$ & $\begin{array}{c}1,4 \cdot 10^{17} \\
\mathrm{p}\end{array}$ & $\begin{array}{c}1,5 \cdot 10^{142} \\
\mathrm{p}\end{array}$
\end{tabular}

Потенційне збільшення швидкості комп'ютера в $10^{3}$ чи навіть в $10^{6}$ разів принципово не вирішить дану проблему (при наявності на мережі більше 20 точок). Таким чином, надзвичайно актуальною задачею $\epsilon$ пошук ефективних шляхів суттєвого зменшення обсягів розрахунків, та/або пошук квазіоптимальних маршрутів, які будуть менш точні ніж оптимальні, однак для визначення яких на ЕОМ достатньо буде декілька секунд.

Для вирішення даної проблеми застосовують методи вирішення задач оптимізації маршруту, класифікація яких наведена на рис.4 [5, 12].

Точні методи гарантують отримання оптимального значення цільової функції, проте вони передбачають складність математичних композицій, ітераційний характер і великий обсяг обчислювальних операцій. Проте навіть 3 використанням потужних ЕОМ оптимальне рішення за прийнятний час 3 використанням деяких 3 цих методів може бути отримане лише для відносно невеликої кількості пунктів.

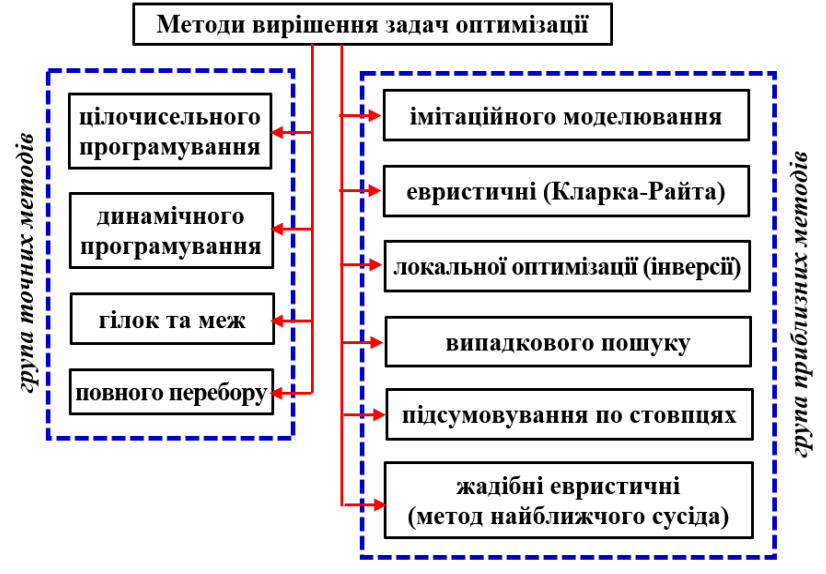

Рис. 4. Класифікація методів вирішення задач оптимізації маршруту

Одним із найбільш поширених точних методів є метод гілок імеж [5, 10-12]. Даний метод застосовує «дерево» рішень та визначає принципи роботи конкретних алгоритмів пошуку рішення. На кожному кроці вся множина маршрутів доставки розбивається на дві непересічних підмножини. Одна підмножина утворює маршрути, які включають дугу $(i-j)$, а інша - маршрути, які цю дугу не включають. У процесі рішення будується «дерево» варіантів, що має в кожній вершині дві гілки. Якщо варіант обходу пунктів однієї з гілок «дерева» має довжину маршруту меншу, ніж нижня межа будь-якої з нерозбитих підмножин, то цей маршрут буде оптимальним.

Приблизні методи дозволяють знаходити рішення задачі в допустимі строки з різними обмеженнями та мають однопрохідний характер розрахунків і використовують відносно простий математичний апарат. При цьому дані методи дають квазіоптимальні рішення (їх похибка може складати понад $10 \%$ ).

Одним із найбільш простих приблизних (евристичних) методів є метод найближчого суcida [13]. Даний метод відноситься до категорії «жадібних» алгоритмів. Пункти, які необхідно відвідати, послідовно включаються у маршрут, причому кожен черговий пункт, що включається, повинен бути найближчим до останнього вибраного пункту серед всіх інших, ще не включених до складу маршруту. Одним з евристичних критеріїв оцінки рішення $є$ правило: якщо маршрут, пройдений на останніх кроках алгоритму, можна порівняти 3 маршрутом, пройденим на початкових етапах, то можна умовно вважати знайдений маршрут прийнятним, інакше, ймовірно, існують кращі рішення.

Виконаємо дослідження ефективності доставки збірних вантажів автомобільним 
транспортом шляхом вирішення задачі комівояжера методами найближчого сусіда та «гілок і меж».

Вирішення задачі будемо виконувати для наведеної на рис. 5 схеми розташування торгових точок деякого міста, які необхідно обслужити автотранспортним підприємством, ефективність роботи якого досліджується.

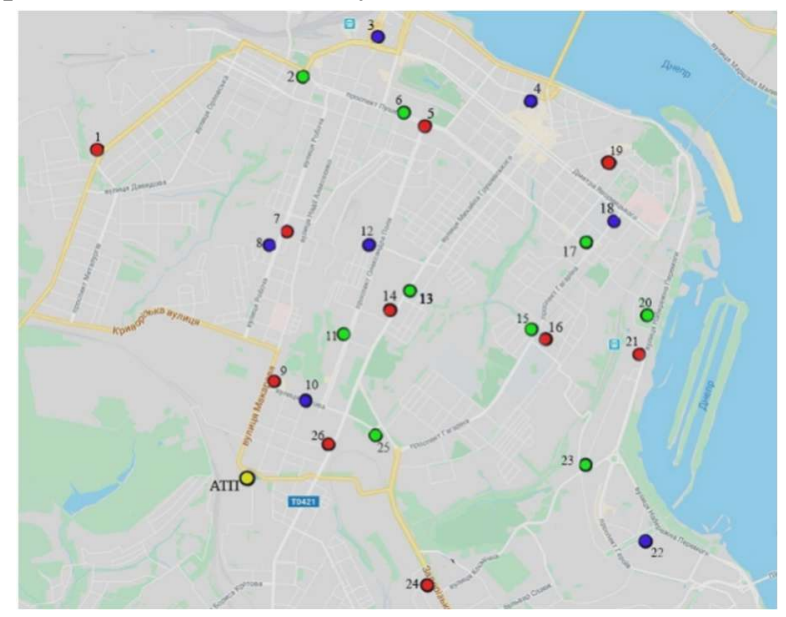

Рис. 5. Схема розміщення торгових точок міста
На базі рис. 5, за допомогою картографічного cepвicy Google була складена матриця відстаней між торговими точками транспортної мережі, що досліджується. Якщо між деякими пунктами немає безпосереднього зв'язку, то в матриці ставиться символ «ю». При визначенні відстаней між точками враховувались пропускна здатність вулиць та напрямки руху транспортних потоків.

В результаті розрахунків отримані наступні параметри кращих маршрутів доставки збірних вантажів кінцевим споживачам для двох, описаних раніше методів, наведені у табл. 2.

Для наочності отримані результати також наведені у графічному вигляді: для методу найближчого сусіда - на рис. $6, a$, для методу «гілок i меж»- на рис. 6, б.

Використовуючи отримані параметри маршрутів доставки збірних вантажів виконаємо порівняльну економічну оцінку методів, що розглядаються. Вартість транспортного обслуговування залежить від встановленого тарифу надання послуг та часу використання автомобіля під час виконання доставки вантажів.

Таблиця 2

Параметри маршрутів доставки збірних вантажів для різних методів

\begin{tabular}{|c|c|c|}
\hline Метод & Кращий маршрут доставки збірних вантажів до торгових точок & $L, \kappa M$ \\
\hline $\begin{array}{l}\text { Найближчого } \\
\text { сусіда }\end{array}$ & 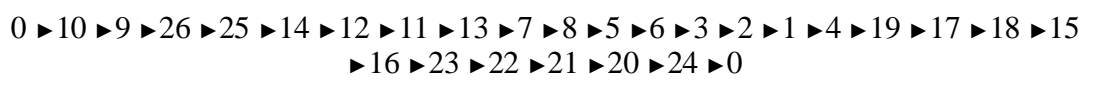 & 67,29 \\
\hline «Гілок та меж» & 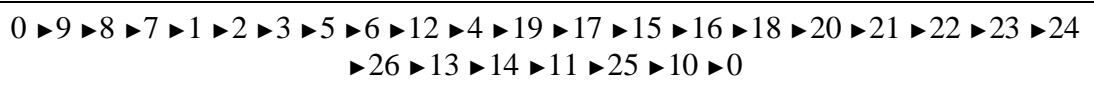 & 60,19 \\
\hline
\end{tabular}
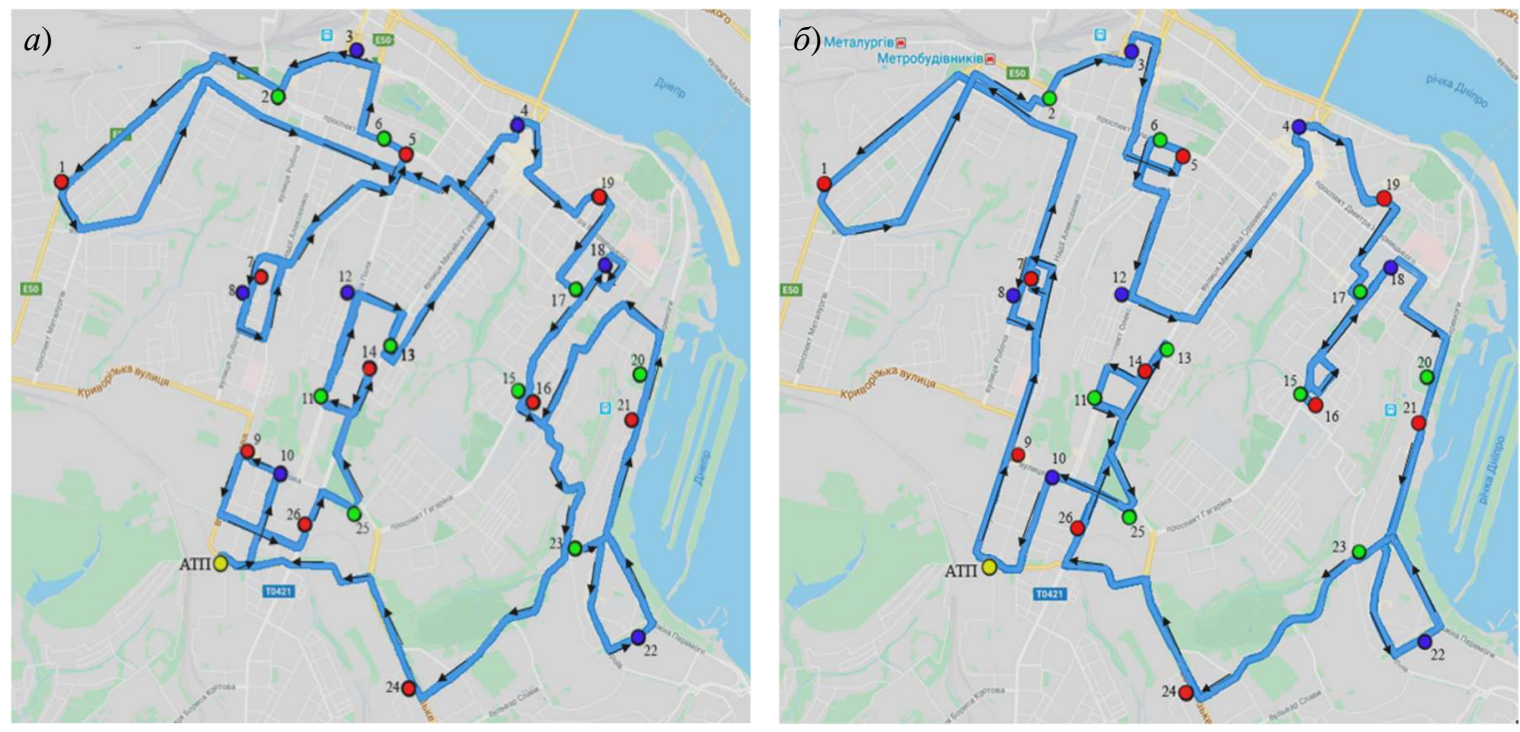

Рис. 6. Порядок доставки збірних вантажів до торгових точок міста: a) метод найближчого сусіда, б) метод «гілок та меж» 
Річна собівартість виконання замовлень може бути визначена за виразом [14]

$$
S_{\mathrm{p}}=365 \cdot K_{\text {зам }} \cdot\left(S_{\text {пост }} \cdot T_{\text {заг }}+S_{\text {зм }} \cdot T_{\mathrm{p}}^{\mathrm{o \sigma}}\right),
$$

де $K_{\text {зам }}$ - кількість замовлень в день, які виконуються на даному маршруті;

$S_{\text {пост }}$ - постійні витрати за годину виконання замовлення;

$T_{\text {заг }}$ - загальна тривалість, що необхідна для виконання замовлення

$S_{\text {зм }}$ - змінні витрати за годину руху;

$T_{\mathrm{p}}^{\text {об }}$ - час руху маршрутом.

Загальну тривалість доставки збірних вантажів можна визначити як

$$
T_{\text {заг }}=t_{\text {зав }}^{\text {скл }}+\sum t_{0}+\sum t_{\mathrm{p}}+\sum t_{\text {в.оп }}+t_{\text {розв }}^{\text {скл }},
$$

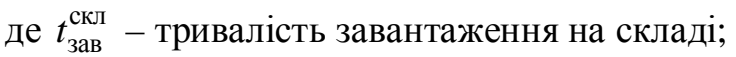

$\Sigma t_{0}$ - тривалість нульових пробігів автомобіля від АТП до складу та навпаки;

$\Sigma t_{\mathrm{p}}$ - загальна тривалість руху автомобілів на маршруті;

$\Sigma t_{\text {в.оп }}-$ тривалість вантажних операцій у торгових точках;

$t_{\text {розв }}^{\text {скл }}-$ тривалість розвантаження автомобіля на складі (за необхідності).

Достовірну оцінку тривалості доставки збірних вантажів згідно [15] можна отримати за виразом

$$
T_{\text {заг }}^{\text {об }}=n \cdot t_{\text {в.оп }}+\frac{L_{\mathrm{M}}}{V_{\mathrm{e}}},
$$

де $n$ - кількість торгових точок на маршруті;

$t_{\text {в.оп }}-$ час вантажних операцій у торговій точці;

$L_{\mathrm{M}}$ - довжина маршруту;

$V_{\mathrm{e}}$ - середня експлуатаційна швидкість руху маршрутом.

Використовуючи все наведене вище, були виконані дослідження, в результаті яких встановлено, що при обслуговуванні торгових точок за квазіоптимальним маршрутом, який було знайдено методом найближчого сусіда, тривалість знаходження на маршруті становитиме 8,0 год, тоді як для оптимального маршруту методу «гілок та меж» ця тривалість складе 7,6 год. В той же час з метою коректної оцінки доцільності пошуку раціонального маршруту з використанням будь-якого із існуючих методів був складений деякий випадковий порядок обслуговування торгових точок, загальна довжина якого склала 81,23 км, а тривалість обслуговування - 8,7 год.

Порівняльна характеристика маршрутів за основними параметрами наведена у табл. 3 .

Таблиця 3

Порівняльна характеристика маршрутів

\begin{tabular}{c|c|c|c}
\hline Параметри & $\begin{array}{c}\text { Довільний } \\
\text { маршрут }\end{array}$ & $\begin{array}{c}\text { Метод } \\
\text { найближчого } \\
\text { сусіда }\end{array}$ & $\begin{array}{c}\text { Метод } \\
\text { гілок і } \\
\text { меж }\end{array}$ \\
\hline$L, \kappa M$ & 81,23 & 67,29 & 60,19 \\
\hline$\Delta L, \%$ & - & $-17,2 \%$ & $-25,9 \%$ \\
\hline$T$, год & 8,7 & 8,0 & 7,6 \\
\hline$\Delta T, \%$ & - & $-8,1 \%$ & $-12,6 \%$ \\
\hline$S_{\mathrm{p}}$, грн & 679130 & 630253 & 602323 \\
\hline$\Delta S_{\mathrm{p}}, \%$ & - & $-7,2 \%$ & $-11,3 \%$
\end{tabular}

Враховуючи отримані результати, можна зробити декілька висновків.

Насамперед слід відмітити, що мінімальні витрати на доставку збірних вантажів отримані для оптимального маршруту, визначеного методом «гілок та меж». Даний результат є закономірним, адже вказаний метод $є$ покращеною версією повного перебору. У той же час варто відмітити і те, що використання даного методу для значної кількості точок на мережі може вимагати дуже багато часу для пошуку оптимального маршруту.

По-друге, слід відзначити, що метод найближчого сусіда хоч і демонструє для свого квазіоптимального маршруту дещо гірші параметри довжини, тривалості роботи та витрат, разом 3 цим він забезпечує суттєву економію витрат у порівнянні $з$ довільно вибраним маршрутом. Важливо відзначити також і те, що реалізація даного методу на ЕОМ дозволить отримати квазіоптимальний маршрут для будь якої мережі за незначний час, хоч і його параметри на $7 \%-20$ $\%$ (в залежності від величини транспортної мережі) можуть бути гіршими ніж параметри оптимального маршруту.

Таким чином, у залежності від кількості точок на мережі та тривалості розрахунків, у ряді ситуацій для пошуку раціонального маршруту доставки збірних вантажів від місць консолідації вантажів до кінцевих споживачів доцільно використовувати метод «гілок та меж», а в інших ситуаціях - метод найближчого сусіда.

3 метою ефективного використання дані методи доцільно реалізувати у вигляді відповідного програмного забезпечення, організувавши тим самим систему підтримки прийняття рішень. 


\section{Висновок}

Проаналізувавши викладений матеріал, можна зробити висновок, що автомобільний транспорт займає важливу роль у формуванні та розвитку економічної, політичної та соціальної складових країни. На сьогодні більша частка вантажних перевезень на короткі відстані припадає саме на автотранспорт. Крім того, хоч дрібнопартійні перевезення становлять незначну частку (близько 3 \%) від загальної транспортної роботи, проте транспортні витрати на ці перевезення можуть складати до $35 \%$ від усіх витрат. Все це викликає необхідність раціональної організації транспортного обслуговування.

Так, у процесі дослідження встановлено, що найбільш ефективним методом для планування маршруту розвезення збірних вантажів $є$ метод «гілок і меж». Саме застосування даного методу дозволяе в будь-яких умовах та при будь-яких відстанях отримати маршрут з найменшою загальною відстанню переміщення автотранспортного засобу, а, отже, і з мінімальними витратами як паливних так і фінансових ресурсів на обслуговування кінцевих споживачів. Однак, за наявності на маршруті дуже значної кількості точок, 3 метою компромісу між швидкістю розрахунків та їх достатньою точністю можна використовувати також і метод найближчого сусіда.

\section{БІБЛІОГРАФІЧНИЙ СПИСОК}

1. Державна служба статистики України [Електронний ресурс]. http://www.ukrstat.gov.ua/

2. Погрібняк О. М. Сучасні умови та особливості правового регулювання перевезень вантажів автомобільним транспортом України / О. М. Погрібняк, А. С. Дорош, Є. Б. Демченко // Транспортні системи і технології перевезень : збір. наук. пр. Дніпр. нац. унту залізн. трансп. ім. акад. В. Лазаряна. - Дніпро, 2018. - Вип. 16. - С. 83-92.

3. Дудар Т. Г., Волошин Р. В. Основи логістики: навч. посіб. / Т. Г. Дудар, Р. В. Волошин - К.: Центр учбової літератури, $2012-176 \mathrm{c}$.

4. Вельможин А. В. Грузовые автомобильные перевозки: учеб. пособие для вузов / А. В. Вельможин - М.: Горячая линия - Телеком, 2006. - 560 с.
5. Никоноров В. М. Математические методы решения задачи маршрутизации мелкопартионных перевозок / В. М. Никоноров // Научно-технические ведомости СПбГПУ. - 2011 - № 6 - С. 222-226.

6. Ширяев, С. А. Особенности функционирования системы доставки грузов в торговую сеть автомобильным транспортом: монография / С. А. Ширяев, С. А. Кащеев; ВолгГТУ. - Волгоград, 2015. $160 \mathrm{c}$.

7. Robertson B. Route optimization is the better way to bigger profits / B. Robertson // Motortruck. - 1984. №5. - C. $27-28$.

8. Просов С. Н. Маршрутизация грузовых автомобильных перевозок: дис. канд. техн. наук / С. Н. Просов // МАДИ-ТУ - 2002. - С. 77 - 92.

9. Домке Э. Р. Методы оптимизации маршрутных схем развозки грузов автомобильным транспортом: учеб. пособие для студ. высш. учеб. завед. / Э. Р. Домке, С. А. Жесткова. - Пенза: ПГУАС, 2014. - 164 c.

10. Литтл Дж. Алгоритм решения задачи коммивояжера / Дж. Литтл и др. // Экономика и математические методы. - 1965. - №1. - С. 94 - 107.

11. Atkinson A., Epstein M. Measure for measure: Realizing the power of the balanced score card // A. Atkinson, M. Epstein // CMA Management. - 2000 - №1 C. 101-103.

12. Ніколаєнко Д. В. Аналіз методів вирішення завдань доставки дрібнопартійних вантажів / Д. В. Ніколаєнко // Вісник ХНУ. - 2013 - № 3, Том 1. C. 195-197.

13. Gutin G., Yeo A., Zverovich A. Traveling salesman should not be greedy: domination analysis of greedy-type heuristics for the TSP / G. Gutin, A. Yeo, A. Zverovich - Discrete Applied Mathematics - 2002 - C. 81-86.

14. Ефанов А. В., Зырянова Н. И. Экономика автотранспортного предприятия: учеб. пособие / А. В. Ефанов, Н. И. Зырянова - Екатеринбург, ГОУ ВПО, $2006-218$ c.

15. Босняк М. Г. Вантажні перевезення: Навчальний посібник для вузів / М. Г. Босняк - К.: Видавничий Дім «Слово», 2010. - 408 с.

Стаття рекомендована до публікаиії д.т.н., проф. Ломотьком Д. В. (Украӥна)

Надійшла до редколегії 12.10.2020

Прийнята до друку 21.10.2020 


\section{ПОВЫШЕНИЕ ЭФФЕКТИВНОСТИ ДОСТАВКА СБОРНЫХ ГРУЗОВ АВТОМОБИЛЬНЫМ ТРАНСПОРТОМ}

Цель. Исследование общепринятой системы организации транспортного обслуживания автотранспортным предприятием, совершенствование технологии планирования перевозок и оптимизация процесса доставки сборных грузов от мест их консолидации к конечным потребителям (предприятиям, складам, торговым точкам, почте и др.). Методика. При формулировании задачи исследования важным является учёт максимального количества наиболее влиятельных факторов: объёмов перевозимых партий грузов; географического положения мест консолидации и погрузки грузов, а также конечных потребителей; тип и грузоподъёмность подвижного состава; сроки доставки грузов; особые условия выполнения погрузочно-разгрузочных работ и т. д. Задача определения оптимального маршрута решалась как задача коммивояжёра с использованием методов комбинаторной оптимизации, логистики и одного из эвристических методов. Результаты. В данной статье были выполнены исследования различных методов планирования маршрута движения автомобиля при доставке сборных грузов к конечным потребителям. В результате были получены рекомендации по выбору метода планирования маршрутов доставки указанных грузов в той или иной ситуации. Практическая значимость. Несмотря на то, что мелкопартионные перевозки составляют незначительную долю от общей транспортной работы, однако транспортные расходы на них составляют около трети всех расходов. В этой связи, рациональное решение вопроса маршрутизации необходимо для эффективного управления перевозочным процессом и сокращения расходов энергетических ресурсов при выполнении транспортной работы по обслуживанию конечных потребителей. Это позволит снизить себестоимость перевозки груза и улучшить экономические показатели работы автотранспортного предприятия в целом.

Ключевые слова: автомобильный транспорт; мелкопартионные грузы; повышение эффективности доставки; задача коммивояжёра; обслуживание конечных потребителей

\section{SKOVRON, A. DOROSH, Y. DEMCHENKO, T. BOLVANOVSKA, V. MALASHKIN}

\section{THE EFFICIENCY IMPROVEMENT OF GROUPAGE CARGO DELIVERY BY ROAD TRANSPORT}

Purpose. The purpose of this article is to study the generally accepted system of transport service, improve the technology of transportation planning and optimize the process of delivery of groupage cargo from the places of their consolidation to end users (enterprises, warehouses, outlets, post offices etc.). Method. When formulating the research task, it is important to take into account the maximum number of the most important factors: the size of the transported consignments; geographical of points of goods storage and loading, as well as end users' location; type and load capacity of rolling stock; terms of delivery; special conditions for carrying out loading and unloading operations, etc. The problem of determining the optimal route was solved as a travelling salesman's problem using the methods of combinatorial optimization, logistics and some heuristic methods. Results. Researches of various methods of the car route planning for the delivery of groupage cargoes to end consumers were carried out. As a result, the recommendations of the method choice for planning the delivery routes of the goods in different situations were given. Practical significance. Despite the fact that groupage cargoes accounts for a small share of total transport work, but transport costs for them reach a third of all costs. In this regard a rational solution of the routing problem is necessary for effective management of the transportation process and reducing the cost of energy resources in the operation of road transport, which will allow to reduce the transportation costs and improve the economic performance of the whole.

Keywords: road transport; groupage cargo; increase of delivery efficiency; travelling salesman problem (TSP); service of end consumers 